\title{
Reproduction by Lake Michigan Fishes in a Tributary Stream ${ }^{1}$
}

\author{
Pamela J. Mansfield \\ Great Lakes Research Division, Institute of Science and Technology \\ University of Michigan, Ann Arbor, Michigan 48109
}

\begin{abstract}
Three common Lake Michigan species (spottail shiner Notropis hudsonius, alewife Alosa pseudoharengus, and white sucker Catostomus commersoni) migrated into Little Pigeon Creek, a Lake Michigan tributary with a marsh upstream, to spawn during 1980. Spottail shiners, not previously documented as spawning in Lake Michigan tributaries, spawned when stream water temperatures reached approximately $18 \mathrm{C}$ ( $7 \mathrm{C}$ warmer than the $1-\mathrm{m}$ depth contour in Lake Michigan), about 1 month earlier in this tributary than in Lake Michigan. Densities of spottail shiner larvae were higher in the stream than in the Lake Michigan beach zone, most likely due to high productivity of the stream and concentration of spawning adults in one area. Little Pigeon Creek produced an estimated 100,000 spottail shiner larvae per day at times of peak hatch, over a 12-day period. White sucker larvae were pelagic in surface waters of the marsh for 1-2 months, then drifted downstream into bottom waters of the stream. Alewife larvae occurred in the tributary 2-3 weeks before peak hatches in Lake Michigan, as stream water continued to be warmer than the lake. Little Pigeon Creek exemplified the importance of small stream systems for reproduction of some Lake Michigan fishes.
\end{abstract}

Data presented here stem from efforts to document more fully the importance of tributary streams for reproduction by Lake Michigan fishes. Evidence has been accumulating that tributaries are more important to the Lake Michigan fauna than previously had been appreciated. Temperatures sufficiently warm to trigger spawning usually occur earlier in the season in tributaries than in Lake Michigan, permitting a longer growth season. Increased growth rates of larvae and young juveniles due to higher temperature may allow greater firstwinter survival as more fish reach a critical size threshold (Christie and Regier 1973). Productivity is often higher in streams than in lakes, as the biota can utilize allochthonous inputs from large terrestrial areas (Waters 1977).

It has been known for many years that white suckers Catostomus commersoni, longnose suckers C. catostomus, and all Salmoninae in Lake Michigan (except, usually, lake trout Salvelinus namaycush) spawn in streams (Scott and Crossman 1973). Recently, the list of lake species that reproduce in tributaries has expanded. Dorr

\footnotetext{
${ }^{1}$ Based on part of a thesis submitted in partial fulfillment of the requirements of the Master of Science degree, Eastern Michigan University, Ypsilanti, Michigan.
}

(1982) found larvae of yellow perch Perca flavescens in the Kalamazoo River and in Lake Michigan at a time when yellow perch spawning had not yet begun in the lake. Two cohorts of yellow perch, one spawned inland (earlier in the season) and one in the lake, have been collected during separate studies on southeastern and eastern Lake Michigan (Wells 1973; Jude et al. 1982; Perrone et al. 1983). Lake Michigan alewives Alosa pseudoharengus spawn in downstream portions of large rivers (Brown 1972). Rainbow smelt Osmerus mordax and burbot Lota lota may spawn in streams feeding eastern Lake Michigan (Jude et al. 1982; Mansfield et al. 1983). Any Lake Michigan tributary is a potential spawning ground for some of these species.

Dunes along the eastern shore, as well as bridges built across rivers, have created many lakes and marshes closely connected to Lake Michigan. This study took place at one such system, Little Pigeon Creek.

\section{Study Site}

Little Pigeon Creek is in Ottawa County, Michigan, $12 \mathrm{~km}$ south of Grand Haven. The stream is approximately $11 \mathrm{~km}$ long, and its watershed has an area of about $21 \mathrm{~km}^{2}$. Lowflow and flood-stage creek discharges were estimated at 0.098 and $1.7 \mathrm{~m}^{3} / \mathrm{second}$, respectively. Near Lake Michigan, flow is impeded by 


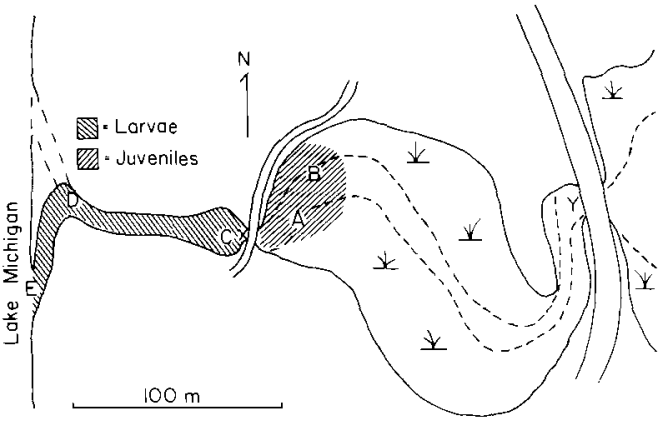

FIGURE 1.-Location of sampling stations $A-E, X$, and $Y$, and distribution of spottail shiner larvae and juveniles in Little Pigeon Creek and marsh, May and June 1980. Dashed line shows channel through marsh.

two bridges with culverts, and marshy areas have resulted (Fig. 1). Boulders and broken concrete riprap surround both culverts, providing spawning habitat for some fish in the fast current over the rocks. Substrate in the marshes is soft organic ooze, whereas that of the stream channel is sand. Emergent vegetation is plentiful in the marshes and submergent vegetation occurs just downstream of the lower culvert, but little or no vegetation exists in the lower $25 \mathrm{~m}$ of the stream. Below the downstream bridge, the stream flows rapidly to the lake. The marsh produces much organic detritus, which is a food source for invertebrates, which in turn provide food for young fish. The still, shallow waters of the marsh warm rapidly in spring, providing proper spawning temperatures early in the season.

\section{Methods}

Sampling was conducted weekly from 17 April to 18 June 1980 and once every 2 weeks thereafter until 17 September. Whenever possible, usually every other week, samples were collected both day and night the same week. Other weeks I sampled only during the day.

Seven sampling stations were placed in representative habitats and in places of most intense current. In the marsh, stations $\mathrm{A}$ and $\mathrm{B}$ were placed on opposite sides of the main channel, at the boundaries of emergent vegetation and open water (Fig. 1). These were the only places found in the marsh with a sufficiently shallow $(1 \mathrm{~m})$ and solid bottom for wading. Station $\mathrm{C}$ (1-m depth) was located at the downstream end of the deepest hole $(2 \mathrm{~m})$, just below the lower culvert. Station D $(0.5 \mathrm{~m})$ was in slow current at the widened bend of the stream approximately $20 \mathrm{~m}$ from the mouth. Station E was in the vicinity of the mouth. When Lake Michigan wave action was low, station- $E$ sampling was conducted within the stream plume out in the lake. When waves were high, station $\mathrm{E}$ was moved just within the stream. Stations $\mathrm{Y}$ and $\mathrm{X}$ were at the downstream ends of the upper and lower culverts, respectively.

\section{Sampling Gear and Techniques}

Two types of gear were used to collect larval fish. Conical 0.5-m-diameter plankton nets with $363-\mu \mathrm{m}$ mesh and Rigosha flowmeters were set in each culvert (stations $\mathrm{Y}$ and $\mathrm{X}$ ) for 2 minutes, in order to obtain quantitative samples of drifting fish larvae at points of fastest current. A plankton net was also towed upstream by hand at station $\mathrm{D}$ for a distance of about $5 \mathrm{~m}$.

A larval-fish seine was towed $5 \mathrm{~m}$ at stations $A$ and $B$, and held stationary to sample drifting larvae at stations $\mathrm{C}$ and $\mathrm{E}$. This seine has a flaring conical cod end with a 1-m-square opening and 363- $\mu \mathrm{m}$ mesh, and 1-m-high $\times 1.2-\mathrm{m}$-wide wings with $760-\mu \mathrm{m}$ mesh. Seine samples were not quantitative. Both plankton net and seine had attachments for collection jars.

Water temperatures were taken at each station and in Lake Michigan each time sampling was conducted. On 3 June 1980 a YSI oxygen meter was used to measure dissolved oxygen at stations $\mathrm{A}, \mathrm{B}$, and $\mathrm{C}$.

Densities and temporal occurrence of fish larvae collected at Little Pigeon Creek were compared with data collected during 1980 near the J. H. Campbell Power Plant, $5 \mathrm{~km}$ south of Little Pigeon Creek. The same type of plankton net used at Little Pigeon Creek was towed 61 $\mathrm{m}$ by hand, against the current (if one was present) along the $1-\mathrm{m}$ depth contour, about $0.5 \mathrm{~km}$ north of the plant (see Jude et al. 1982 for details). The plant discharge is offshore at the $6-\mathrm{m}$ depth contour, and tows in the beach zone should not have been influenced by the discharge plume.

A 4-m minnow seine with $6-\mathrm{mm}$ bar mesh was used to collect juvenile and adult fish at stations A-E. Both shorelines on either side of station $C$ were sampled. Seining at station $\mathbf{E}$ was conducted in Lake Michigan when possible, and upstream from the mouth when waves were high. Stations A, B, and D were seined along 
extensions of the same line on which larvae tows were done. Minnow-seine hauls were approximately $8 \mathrm{~m}$ long. Adult fish were squeezed gently to see if they were ripe-running.

\section{Sample Processing}

Fish larvae and egg samples were preserved with $10 \%$ formalin buffered with borax. In the laboratory, fish larvae (and any juveniles, fish with all fin rays developed) were identified to species, measured to the nearest $0.5 \mathrm{~mm}$, and stored in 5\% buffered formalin. Fish eggs in each sample were counted, and the first 25 were stored. Size, adhesive characteristics, and time of occurrence sometimes permitted a tentative identification of eggs.

Calibrated flowmeter readings from plankton net samples were used to calculate densities (number $/ \mathrm{m}^{3}$ ) of fish larvae and eggs (Jude et al. 1982). I assumed no bias arose from sampling with towed nets in the lake versus stationary nets in the stream current. Sample volumes ranged from 0.5 to $23 \mathrm{~m}^{3}$ at Little Pigeon Creek and from 2 to $11 \mathrm{~m}^{3}$ at Campbell. Both day and night larva densities were used in calculations, because it was unknown whether observed diel differences were due to net avoidance or degree of drift taking place.

\section{Discharge Estimation and Comparisons}

Discharge of Little Pigeon Creek was estimated from flowmeter readings (current speed) in the lower culvert, where cross-sectional area could be calculated. Estimates were made for a flood stage (14 April 1981) and a period of lesser flow, representative of the spawning season for most species (5 May 1981). Discharge estimates were used to extrapolate fish-larva densities in samples to estimates of drifting larvae produced in the stream above station X.

Watershed areas of Little Pigeon Creek and other tributary streams were estimated from topographic maps. Presence of wetlands or bridges was noted.

\section{Results}

Ripe-running spottail shiners Notropis hudsonius were collected from 22 May through the end of June at all stations from the lower culvert downstream. Largest concentrations of spawning adults were observed during the nights of 22 May and 4 June at stations close to the lower culvert ( $\mathrm{X}$ and $\mathrm{C}$ ). Broken concrete and rock at
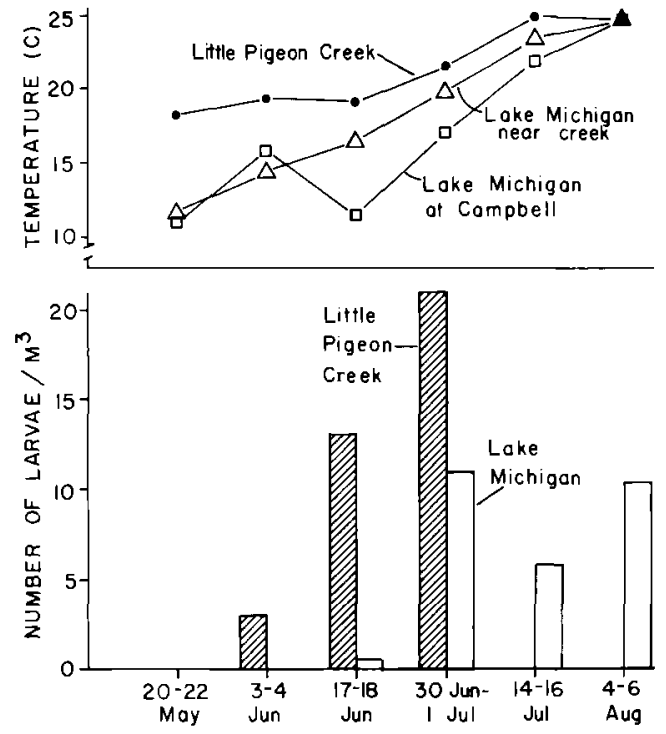

Figure 2.-Densities of spottail shiner larvae and water temperatures during night collections from station $X$, Little Pigeon Creek, and the $1-m$ depth contour of Lake Michigan $5 \mathrm{~km}$ south at the Campbell Plant (Jude et al. 1981), May-August 1980. Also shown are water temperatures in Lake Michigan 10-20 $\mathrm{m}$ from the creek mouth, outside of the plume.

the lower culvert appeared to be a preferred spawning site. Fish eggs were collected from 22 May through 30 June at all stations downstream of the lower culvert, but most consistently at the culvert where spawning was most concentrated and the intense current carried the eggs to the net before they could sink into crevices. Most eggs collected during late May were believed to be spottail shiner eggs, based on size of eggs $(1 \mathrm{~mm})$, abundance of spawning adult spottail shiners, and absence of other ripe-running fish from minnow-seine samples. Yolk-sac larvae occurred at all stations downstream of the lower culvert from 27 May to 30 June (Fig. 1). Postyolk-sac larvae and juveniles were collected infrequently during summer at most stations.

Spottail shiners spawned when temperatures in Little Pigeon Creek reached 18 C (22 May); spawning occurred about 1 month earlier in the creek than observed in Lake Michigan by Jude et al. (1981). Spottail shiner larvae were collected in Little Pigeon Creek 2 weeks earlier (27 May) and in higher densities than in Lake Michigan near the Campbell Plant (Fig. 2). At 
the time spottail shiners began to spawn in the creek, Lake Michigan's water temperature was about $12 \mathrm{C}$ near the creek mouth. When spottail shiner larvae began to appear in Little Pigeon Creek, Lake Michigan was 4 to $9 \mathrm{C}$ cooler than the creek. However, during mid- and late June, when peak larva densities were recorded in the creek, the lake was only 2 to $3 \mathrm{C}$ cooler (Fig. 2).

Spottail shiner was the only species whose larvae were collected consistently enough to merit quantitative treatment. Newly hatched spottail shiner larvae were collected at station $\mathrm{X}$ from 4 June to 30 June, at densities of 0 to 21 larvae/ $\mathrm{m}^{3}$. Mean density for the month was 7.3 larvae/ $\mathrm{m}^{3}$. At an estimated stream discharge of 0.098 $\mathrm{m}^{3} /$ second (period of low flow), 1.8 million spottail shiner larvae would have drifted to Lake Michigan during June, if all larvae from station $\mathrm{X}$ reached the lake. Peak abundance occurred during 18-30 June; mean density was 14 lar$\mathrm{vae} / \mathrm{m}^{9}$, resulting in an estimated 120,000 spottail shiner larvae per day drifting to Lake Michigan, or 1.4 million over 12 days. Mean density for $18-19$ June was $17 / \mathrm{m}^{9}$, the highest of any 24-hour period during the study; thus the maximum contribution of spottail shiner larvae to Lake Michigan during 1 day was 140,000 .

Eggs believed to be those of white sucker (presence of spawning adults; egg diameter 3 $\mathrm{mm}$ ) were collected at the upper (station $\mathrm{Y}$ ) and lower (X) culverts and just below the lower culvert (C) from mid-April to early May. Mean egg density was $15 / \mathrm{m}^{3}$. Spawning white suckers penetrated upstream to the upper culvert, which was farther than spottail shiners migrated. During late May and early June, white sucker larvae were observed schooling in surface waters of the marsh. Because of the possibility that dissolved-oxygen deficiency affected larva behavior, dissolved oxygen was measured and found to be at $86 \%$ of saturation in bottom marsh waters. During June, older larvae and juvenile white suckers were seen in bottom waters downstream of station $\mathrm{X}$. Juveniles were collected both in the marsh and below the lower culvert, and none were seen in surface waters. Few white suckers of any size were taken in drift samples, and none were taken by any method after the end of June.

Spawning adult alewives were collected on 4 June at downstream stations D and E. Many eggs collected on that date were believed to be alewife eggs, because egg densities (up to 179/ $\mathrm{m}^{3}$ ) were higher than they had been during peak spottail shiner spawning ( 1 to 14 eggs $/ \mathrm{m}^{3}$ ), and alewife eggs tend to be more pelagic than spottail shiner eggs (Auer 1982), thus are more likely to be collected in drift samples. Yolk-sac alewife larvae were collected on 30 June at station $\mathrm{C}$ just below the lower culvert, indicating spawning adult alewives had moved upstream at least that far.

Yearling emerald shiners Notropis atherinoides frequently were taken by minnow seine at stations downstream of the lower culvert during spring. No emerald shiner larvae or adults were collected in Little Pigeon Creek, suggesting emerald shiners spawn elsewhere.

\section{Discussion}

Spottail shiners are lake residents not previously documented as spawning in streams, except in eastern Lake Superior (Scott and Crossman 1973). This species is unlikely to migrate upstream any great distance. At Little Pigeon Creek, spawning was observed $100 \mathrm{~m}$ from the mouth, but not where similar habitat existed $300 \mathrm{~m}$ from the mouth. Many of the demersal, adhesive eggs of spottail shiner no doubt sank into the interstices of the rocks and incubated there, rather than immediately drifting to Lake Michigan.

High densities of drifting larvae were recorded shortly after hatching occurred. A peak density of $21 / \mathrm{m}^{3}$ occurred twice, in samples 12 days apart, suggesting extended periods of such densities may have occurred. At a relatively low discharge of $0.098 \mathrm{~m}^{3} /$ second, typical of Little Pigeon Creek during peak spottail shiner spawning, over 100,000 spottail shiner larvae entered Lake Michigan per day. Therefore, Little Pigeon Creek represents a potentially important contribution to Lake Michigan spottail shiner populations, particularly in consideration that larva densities were lower in the lake, and earlier spawning in the creek may have enhanced survival.

Liston et al. (1981) estimated 346,000 spottail shiner larvae were present during late June in an area of Lake Michigan $2.4 \times 9.7 \mathrm{~km}$ extending from the shore to the $13.7-\mathrm{m}$ depth contour near Ludington, $104 \mathrm{~km}$ north of Little Pigeon Creek. Production of over 100,000 fish larvae per day in a tributary stream could be an important part of the budget in such an area. 
However, there were an estimated 11.4 million spottail shiner larvae in the Campbell Plant area $(7.1 \times 2.8 \mathrm{~km})$ during a 24 -hour period in late June 1981 (Jude et al. 1982), so the daily contribution of Little Pigeon Creek would have been only about $1 \%$ of the local population.

In addition to Little Pigeon Creek, there are 10 streams with watersheds 10 to $30 \mathrm{~km}^{2}$ feeding eastern Lake Michigan between Michigan City, Indiana, and Frankfort, Michigan. Eight of these streams have bridges within $1 \mathrm{~km}$ of their mouths, and five have wetlands in their watersheds, both characteristics shared with Little Pigeon Creek. Bridges may constrict stream flow, increasing water velocity and decreasing siltation at that point, as in Little Pigeon Creek. These 10 other streams may serve as spawning sites for different species than Little Pigeon Creek, but each may also contribute important numbers of fish larvae to its local area during the season.

Spottail shiners usually spawn at water temperatures of 15-20 C (Auer 1982). The earlier occurrence of suitable spawning temperatures in Little Pigeon Creek (or inland waters generally) than in Lake Michigan may result in higher survival rates in the stream cohort, because higher water temperatures induce faster growth (Taniguchi 1981), promote survival (Koonce et al. 1977), and by increasing growth rates may allow for higher winter survival (Christie and Regier 1973).

Inland-spawned fish larvae encounter cooler water temperatures when they reach Lake Michigan. Seven-day-old larvae of walleye Stizostedion vitreum reared at $21 \mathrm{C}$ all survived when placed in $16 \mathrm{C}$ water for 72 hours (Smith and Koenst 1975), a greater temperature difference than was experienced by most spottail shiners at Little Pigeon Creek. Cold shock increased susceptibility of juvenile channel catfish Ictalurus punctatus and bluegill Lepomis macrochirus to predation (Coutant et al. 1974, 1976; Wolters and Coutant 1976), but temperature differences generally had to be more than $6 \mathrm{C}$ to produce significantly more predation. At the time when most spottail shiner larvae from Little Pigeon Creek entered Lake Michigan, water temperatures differed by only 2-3 C, and fewer of their predators were likely to be near shore than would be a month later (Jude et al. 1981). In June 1980, yearling emerald shiners, which were potential predators of spottail shiner lar- vae, were seined at stations $C$ and $D$, but were not as common as they had been during April. Also during June, yearling alewives, adult spottail shiners, and a few yearling rainbow smelt were collected by seine at the Campbell Plant $5 \mathrm{~km}$ south (Jude et al. 1981). These were the only species commonly seen near shore at that time, and it is not known whether or not any of them preyed upon spottail shiner larvae.

Little drift of white sucker larvae was detected in Little Pigeon Creek. Geen et al. (1966) found downstream movement of white and longnose suckers was greatest during high stream levels, very dark nights, or high turbidity, peaking about 1 month after spawning. The sampling schedule at Little Pigeon Creek may have missed peak drift or white sucker larvae may have avoided the nets. White sucker larvae probably are better swimmers than spottail shiner larvae because sucker larvae are larger and adapted for life in streams. Stream dwellers may depend more on swimming ability than limnetic species (Houde 1969).

The shift from surface to bottom waters exhibited by white suckers coincided with the period when their mouths moved from a terminal to a ventral position. White sucker larvae feed first at the surface, then begin bottom feeding at lengths of $16-18 \mathrm{~mm}$ when the mouth changes (Scott and Crossman 1973). Surface schooling was evidently not a response to low dissolved oxygen in bottom waters, because measurements showed oxygen was near saturation just above the marsh bottom. After this shift, white suckers in Little Pigeon Creek became more abundant in swifter downstream waters, presumably because their increased size allowed them to cope with the current. They probably moved into Lake Michigan after June, because none were caught from July through August.

Lake Michigan alewives spawn both in the lake (Jude et al. 1982) and in large rivers (Brown 1972). Given their abundance in the lake and the few spawners observed in Little Pigeon Creek, the stream probably is not as important a spawning site for alewives as it is for spottail shiners or white suckers. Many eggs were collected near the stream mouth during the alewife spawning period, but few alewife larvae were taken, suggesting most alewife eggs drift to the lake before hatching.

Emerald shiners spawn both in Lake Michigan and in a connecting lake by the Campbell 
Plant (Jude et al. 1981), but no evidence was found that they spawned in Little Pigeon Creek. Adults are primarily pelagic in the Great Lakes (Flittner 1964). Abundant food may have attracted juvenile emerald shiners to Little $\mathrm{Pi}$ geon Creek.

\section{Acknowledgments}

Consumers Power Company, Jackson, Michigan provided partial funding. I thank George Heufelder, who originally suggested the study, Nancy Auer, Heang Tin, and others who assisted with sampling, and Mary Sweeney who processed some samples. Thanks also to Dale Wallace and David Jude who reviewed the manuscript and to Janet Huhn who typed it.

\section{References}

Auer, N. A., editor. 1982. Identification of larval fishes of the Great Lakes basin with emphasis on the Lake Michigan drainage. Great Lakes Fishery Commission, Special Publication 82-3, Ann Arbor, Michigan, USA.

Brown, E. H., JR. 1972. Population biology of alewives, Alosa pseudoharengus, in Lake Michigan, 1949-70. Journal of the Fisheries Research Board of Canada 29:477-500.

Christie, W. J., and H. A. Regler. 1973. Temperature as a major factor influencing reproductive success of fish-two examples. Rapports et ProcèsVerbaux des Réunions, Conseil International pour l'Exploration de la Mer 164:208-218.

Coutant, C. C., D. K. Cox, And K. W. Moored, Jr. 1976. Further studies of cold-shock effects on susceptibility of young channel catfish to predation. Pages 154-158 in G. W. Esch and R. W. McFarlane, editors. Thermal ecology II. Technical Information Center, Energy Research and Development Administration, Washington, District of Columbia, USA.

Coutant, C. C., H. M. Ducharme, JR., and J. R. FISHER. 1974. Effects of cold shock on vulnerability of juvenile channel catfish (Ictalurus punctatus) and largemouth bass (Micropterus salmoides) to predation. Journal of the Fisheries Research Board of Canada 31:351-354.

DorR, J. A., III. 1982. Substrate and other environmental factors in reproduction of the yellow perch (Perca flavescens). Doctoral dissertation. University of Michigan, Ann Arbor, Michigan, USA.

FlitTner, G. A. 1964. Morphometry and life history of the emerald shiner, Notropis atherinoides Rafinesque. Doctoral dissertation. University of Michigan, Ann Arbor, Michigan, USA.

Geen, G. H., T. G. Northcote, G. F. Hartman, and C. C. LINDSEY. 1966. Life histories of two species of catostomid fishes in Sixteenmile Lake, British
Columbia, with particular reference to inlet spawning. Journal of the Fisheries Research Board of Canada 23:1761-1788.

Houde, E. D. 1969. Sustained swimming ability of larvae of walleye (Stizostedion vitreum vitreum) and yellow perch (Perca flavescens). Journal of the Fisheries Research Board of Canada 26:16471659.

Jude, D. J., AND eight CoAuthors. 1981. Adult, juvenile and larval fish populations in the vicinity of the J. H. Campbell Power Plant, eastern Lake Michigan, 1977-1980. Great Lakes Research Division Special Report 86, University of Michigan, Ann Arbor, Michigan, USA.

Jude, D. J., AND SeVen COAuthors. 1982. Adult, juvenile and larval fish populations in the vicinity of the J. H. Campbell Plant, 1981, with special reference to the effectiveness of wedge-wire intake screens in reducing entrainment and impingement of fish. Great Lakes Research Division Special Report 96, University of Michigan, Ann Arbor, Michigan, USA.

Koonce, J. F., T. B. Bagenal, R. F. Carline, K. E. F. Hokanson, and M. Naglf̧c. 1977. Factors influencing year-class strength of percids: a summary and a model of temperature effects. Journal of the Fisheries Research Board of Canada 34: 1900-1909.

Liston, C. R., D. Brazo, R. O’Neal, J. Bohr, G. Peterson, And R. Ligman. 1981. Assessment of larval, juvenile, and adult fish entrainment losses at the Ludington Pumped Storage Power Plant on Lake Michigan. Department of Fisheries and Wildlife, Annual Report (1980) to Consumers Power Company, Ludington Project, Volume 1, Michigan State University, East Lansing, Michigan, USA.

Mansfield, P. J., D. J. Jude, D. T. Michaud, D. C. Brazo, And J. Gulvas. 1983. Distribution and abundance of larval burbot and deepwater sculpin in Lake Michigan. Transactions of the American Fisheries Society 112:162-172.

Perrone, M., Jr., P. J. Schneeberger, and D. J. Jude. 1983. Distribution of larval yellow perch (Perca flavescens) in nearshore waters of southeastern Lake Michigan. Journal of Great Lakes Research 9:517-522.

Scott, W. B., And E. J. Crossman. 1973. Freshwater fishes of Canada. Fisheries Research Board of Canada Bulletin 184.

Smith, L. L., JR., And W. M. Koenst. 1975. Temperature effects on eggs and fry of percoid fishes. Environmental Protection Agency Ecological Research Series 660/3-75-017, Corvallis, Oregon, USA.

TAniguchi, A. K. 1981. Survival and growth of larval spotted seatrout (Cynoscion nebulosus) larvae in relation to temperature, prey abundance and stocking densities. Rapports et Procès-Verbaux des Réunions, Conseil International pour l'Exploration de la Mer 178:507-508. 
WATERS, T. F. 1977. Secondary production in inland waters. Advances in Ecological Research 10:91164.

WELLS, L. 1973. Distribution of fish fry in nearshore waters of southeastern and east-central Lake Michigan, May-August 1972. Great Lakes Fishery Laboratory Administrative Report, Ann Arbor, Michigan, USA.
Wolters, W. R., and C. C. Coutant. 1976. The effect of cold shock on the vulnerability of young bluegill to predation. Pages 162-164 in G. W. Esch and R. W. McFarlane, editors. Thermal ecology II. Technical Information Center, Energy Research and Development Administration, Washington, District of Columbia, USA. 